\title{
BIOLOGY OF ZINC AND BIOLOGICAL VALUE OF DIETARY ORGANIC ZINC COMPLEXES AND CHELATES
}

\author{
JOHANNES W. G. M. SWINKELS ${ }^{123}$, ERVIN T. KORNEGAY ${ }^{1}$
} AND MARTIN W. A. VERSTEGEN 4

${ }^{1}$ Department of Animal Science, Virginia Polytechnic Institute and State University, Blacksburg, VA 24061, USA

${ }^{2}$ Current address: Research Institute for Pig Husbandry, P.O. Box 83, 5240 AB Rosmalen, The Netherlands

${ }^{3}$ The author was a Pratt Fellow and this research was supported by the John Lee Pratt Animal Nutrition Foundation

${ }^{4}$ Department of Animal Nutrition, Agricultural University of Wageningen, Haagsteeg 4, 6708 PM Wageningen, The Netherlands

\section{CONTENTS}

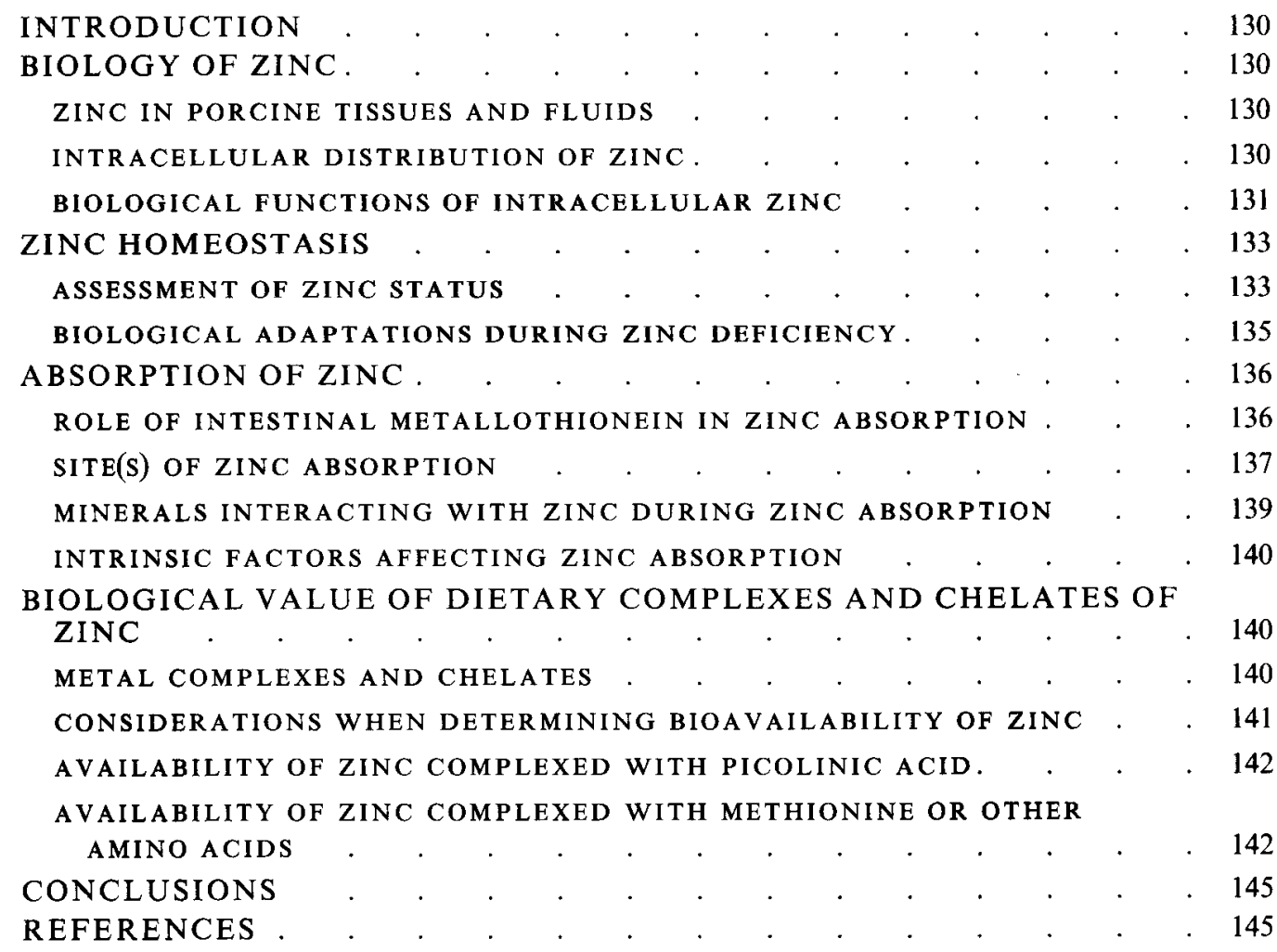




\section{INTRODUCTION}

Growth retardation and an abnormal hair coat, induced in rats by feeding a purified diet low in $\mathrm{Zn}(1.6$ p.p.m. $\mathrm{Zn}$ ), were the first clinical signs associated with dietary $\mathrm{Zn}$ deficiency (Todd et al. 1934). Two decades later, a direct relationship between $\mathrm{Zn}$ and growth was reported for swine (Tucker \& Salmon, 1955). In addition to impaired growth in the $\mathrm{Zn}$ deficient pigs, Tucker \& Salmon (1955) also observed dermatosis that was previously called 'parakeratosis' by Kernkamp \& Ferrin in 1953. Parakeratosis is the classic characteristic associated with severe $\mathrm{Zn}$ deficiency in swine (National Research Council, 1979).

Since the recognition of $\mathrm{Zn}$ as an essential nutrient, many researchers have studied the role of $\mathrm{Zn}$ in biology and nutrition. In the first section of this paper the biology of $\mathrm{Zn}$ is reviewed. This is followed by an overview of our current understanding of possible modes of action of $\mathrm{Zn}$ absorption. In the last part the biological value of dietary organic $\mathrm{Zn}$ complexes and $\mathrm{Zn}$ chelates is discussed.

\section{BIOLOGY OF ZINC}

\section{ZINC IN PORCINE TISSUES AND FLUIDS}

The concentration of $\mathrm{Zn}$ in the whole body of the pig, expressed on a fat free basis, is $25 \mathrm{mg} / \mathrm{kg}$ (Spray \& Widdowson, 1950). This is within the $20-30 \mathrm{mg} / \mathrm{kg}$ range reported for fat free bodies of rats, cats, man (Spray \& Widdowson, 1950), sheep (Grace, 1983) and dairy cows (Miller et al. 1974). In Table 1, concentrations of $\mathrm{Zn}$ in tissues, fluids, bone and integuments of the pig are presented. These concentrations were similar to those found in body compartments of rats, sheep, cows, monkeys and men (Hambidge et al. 1986; Jackson, 1989).

In pigs, the highest concentration of $\mathrm{Zn}$ is found in hair. However, relative to the $\mathrm{Zn}$ content of the whole body the total amount of $\mathrm{Zn}$ in hair is small. The largest pool of $\mathrm{Zn}$, approximately $60 \%$, is found in skeletal muscle tissue because of its bulk and fairly high $\mathrm{Zn}$ concentration (Jackson, 1989). The concentration of $\mathrm{Zn}$ varies with the type of skeletal muscle, being highest in red and lowest in white skeletal muscle (Cassens et al. 1967). The remainder of the $\mathrm{Zn}$ pool of the body is primarily located in bone and organs. Body fluids contain only a small proportion of total body $\mathrm{Zn}$ (Hambidge et al. 1986).

The total $\mathrm{Zn}$ content of the body on a weight basis remains fairly constant from birth to maturity (Spray \& Widdowson, 1950). The relative proportion of body $\mathrm{Zn}$ found in the liver gradually increases from birth to weaning. After weaning, the liver $\mathrm{Zn}$ concentration rapidly decreases to approximately the level of $\mathrm{Zn}$ present at birth (Spray \& Widdowson, 1950).

\section{INTRACELLULAR DISTRIBUTION OF ZINC}

In mouse liver cells, the largest proportion of intracellular $\mathrm{Zn}$ was found in the light fraction containing organelles other than mitochondria and nuclei (Bartholomew et al. 1959). Conversely, in porcine muscle cells the largest concentration of $\mathrm{Zn}$ was found in the heavy fraction containing myofibrils and nuclei (Cassens et al. 1967). Moreover, it was found that the level of $\mathrm{Zn}$ in the heavy fraction of red skeletal muscle was almost four times as high as in white skeletal muscle. The $\mathrm{Zn}$ level in the light fraction was equally low for both the red and white muscle types (Cassens et al. 1967). Thus, the intracellular distribution of $\mathrm{Zn}$ varies among tissues.

It is much harder to determine the nature of intracellular $\mathrm{Zn}$ than its location. Most biochemical techniques currently available involve destruction of the cell allowing $\mathrm{Zn}$ to 
Table 1. Concentration of $Z n$ in body fluids and tissues of fast growing pigs ${ }^{a}$

\begin{tabular}{|c|c|}
\hline Item & Concentration \\
\hline \multicolumn{2}{|l|}{ Blood } \\
\hline Plasma $(\mu \mathrm{g} / \mathrm{l})$ & 740 \\
\hline Serum $(\mu \mathrm{g} / \mathrm{l})$ & 600 \\
\hline Erythrocytes $(\mu \mathrm{g} / \mathrm{g}$ packed cells) & $7 \cdot 7$ \\
\hline Leucocytes $^{\mathrm{b}}$ do/ $\mathrm{P}$ & $21 \cdot 5$ \\
\hline \multicolumn{2}{|l|}{ Tissues $^{\mathrm{b}}$} \\
\hline Bone & 113 \\
\hline Brain & 70 \\
\hline Heart & 96 \\
\hline Kidney & 141 \\
\hline Liver & 151 \\
\hline Red muscle & 137 \\
\hline Mixed muscle & 89 \\
\hline White muscle & 67 \\
\hline Pancreas & 161 \\
\hline Spleen & 107 \\
\hline \multicolumn{2}{|l|}{ Integuments $^{\mathrm{b}}$} \\
\hline Hair & 201 \\
\hline Skin & 28 \\
\hline
\end{tabular}

a Data compiled from Hoekstra et al. (1956, 1967), Cassens et al. (1967), Miller et al. (1968), Crofton et al. (1983) and Zhou et al. (1994).

"Data of leucocytes, tissues and integuments are expressed as p.p.m. on a DM basis.

exchange ligands prior to analysis of $\mathbf{Z n}$ binding compounds (Jackson, 1989). Nevertheless, it has become apparent that $\mathrm{Zn}$ is part of many cellular metalloenzymes (Galdes \& Vallee, 1983 ) and that $\mathrm{Zn}$ binds readily to the thiolate ligands present in the cellular protein metallothionein (Vasak \& Kägi, 1983).

The distribution and nature of intracellular $\mathrm{Zn}$ is depicted in Fig. 1. Zinc is found in many cell compartments and is largely bound to cellular proteins (Williams, 1984). However, this does not exclude the existence of substantial amounts of free intracellular $\mathrm{Zn}$ or intracellular $\mathrm{Zn}$ complexed with one or more free amino acids (Jackson, 1989).

\section{BIOLOGICAL FUNCTIONS OF INTRACELLULAR ZINC}

To date, it has been suggested that $\mathrm{Zn}$ is involved in the following biological processes: (1) catalysis, (2) structural arrangement of protein, and (3) regulation of cellular events (Williams, 1989). For each of the processes, $\mathrm{Zn}$ exerts its biological activity almost entirely as part of complex molecules.

The catalytic function of $\mathrm{Zn}$ is clearly demonstrated in the enzyme carbonic anhydrase (Galdes \& Vallee, 1983). The only physiological reaction known to be catalysed by carbonic anhydrase is the reversible hydration of carbon dioxide $\left(\mathrm{H}_{2} \mathrm{O}+\mathrm{CO}_{2}=\mathrm{H}^{+}+\mathrm{HCO}_{3}^{-}\right)$. The $\mathrm{Zn}$ ion of carbonic anhydrase is thought to participate in the first step of the catalytic reaction. Basically, $\mathrm{Zn}$ functions as an electron acceptor, or Lewis acid, and binds to the $\mathrm{H}_{2} \mathrm{O}$ molecule. Due to the neutral imidazole ligands of the enzyme, the complex $\mathrm{Zn}\left(\mathrm{H}_{2} \mathrm{O}\right)$ attains maximum acidity making ionization of $\mathrm{H}_{2} \mathrm{O}$ to $\mathrm{OH}^{-}$possible at $\mathrm{pH} 7$ (Williams, 1989). The reactivity of the nucleophilic $\mathrm{OH}^{-}$group is sufficient for carbonic anhydrase to attack the electrophilic $\mathrm{CO}_{2}$ molecule. As a result, the end product $\mathrm{HCO}_{3}{ }^{-}$is formed (Galdes \& Vallee, 1983). Zinc is thought to behave in a similar way in other $\mathbf{~ Z n}$ metalloenzymes which contain $\mathrm{Zn}$ at the active site. 


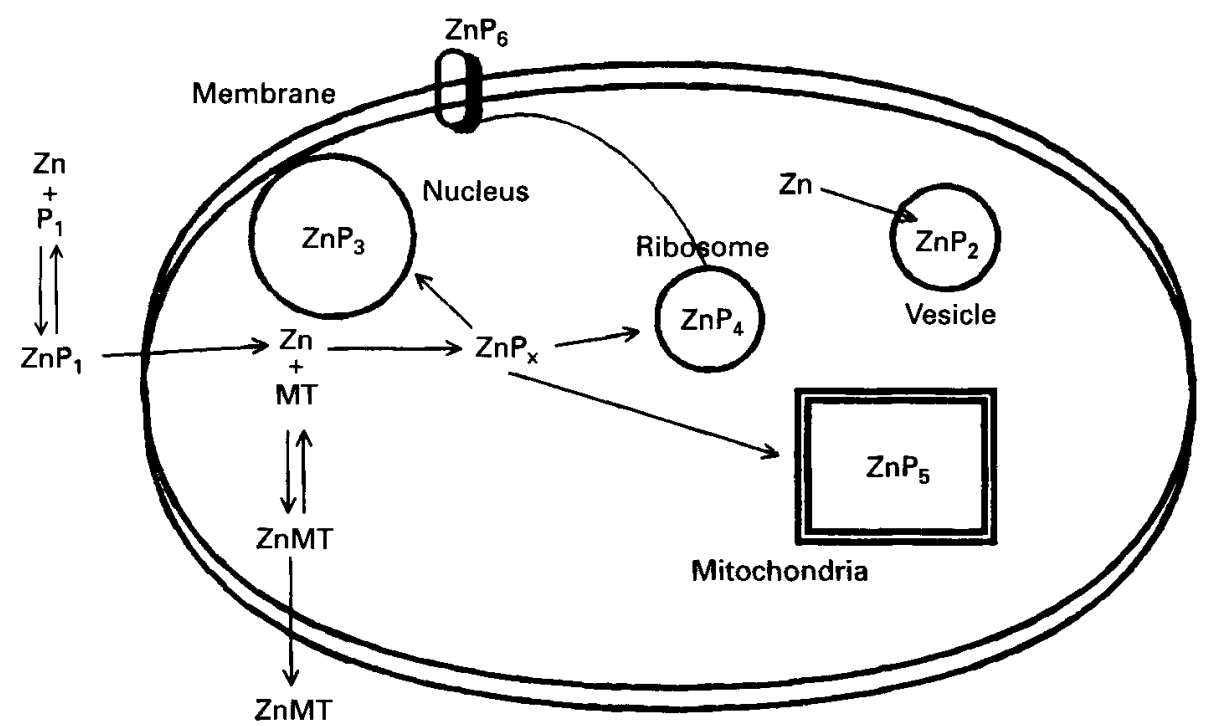

Fig. 1, Outline of the distribution of intracellular $\mathrm{Zn}$ (Williams, 1984). Zinc is carried to the cell by an extracellular protein carrier $\left(\mathrm{ZnP}_{1}\right)$. After being transported into the cell, free $\mathrm{Zn}$ can bind to intracellular metallothionein (MT) or other intracellular proteins $\left(\mathrm{ZnP}_{\mathbf{x}}\right)$. Metallothionein binds $\mathrm{Zn}(\mathrm{ZnMT})$ and functions either as an intracellular storage protein or as an extracellular protein carrier. Zinc can also be transferred outside the cell as a constituent of enzymes or hormones $\left(\mathrm{ZnP}_{2}\right)$. Intracellularly, $\mathrm{Zn}$ is transported to different cellular compartments in which it carries out important biological functions. Nuclear $\left(\mathrm{ZnP}_{3}\right)$, ribosomal $\left(\mathrm{ZnP}_{4}\right)$ and mitochondrial $\left(\mathrm{ZnP}_{5}\right)$ proteins may be involved in polymerization, catalysis or protection. Zinc-containing enzymes or transporter proteins $\left(\mathrm{ZnP}_{6}\right)$, produced at the ribosomes, can be incorporated into the cell membrane.

Zinc may play a structural role in enzymes whenever it is located in a site not critical for catalysis. Furthermore, $\mathrm{Zn}$ is considered of critical importance in maintaining the structure of metalloproteins such as insulin and growth hormone. In this sense, $\mathrm{Zn}$ can be viewed as a replacement for a disulphide bond, a common feature in many proteins that provides stability by interlinking polypeptide chains (Stryer, 1988).

One disadvantage of the disulphide bond is that in a reducing environment the sulphur containing amino acids of the protein chain can be protonated. Protonation causes a breakup of the disulphide bridge so that protein conformation is lost. A second disadvantage of the disulphide bridge is that it allows little motion about itself and therefore restricts protein conformation. In contrast to the disulphide bridge, $\mathrm{Zn}$ cannot be reduced and puts very little stereochemical demand on the protein (Williams, 1984). Thus, $\mathrm{Zn}$ provides enzymes and other $\mathrm{Zn}$-containing proteins with conformational stability at various $\mathrm{pH}$ without causing much steric hindrance.

A possible cooperative role of $\mathrm{Zn}$ and enzymes has been recognized in regulation of metabolic processes and synthesis (Jackson, 1989). Moreover, evidence has been presented that $\mathrm{Zn}$ is involved in gene expression of metallothionein (Seguin \& Hamer, 1987). Recently, Cousins \& Lee-Ambrose (1992) used rats to investigate the interactions of dietary $\mathrm{Zn}$ intake, nuclear $\mathrm{Zn}$ uptake and metallothionein gene expression. They reported that increases in dietary $\mathrm{Zn}$ were proportional to nuclear uptake of ingested $\mathrm{Zn}$ as well as to the level of metallothionein gene expression in the kidney, liver, intestine, spleen and heart. Using heparin-Sepharose chromatography and South-Western blotting, several Zn-binding protein fractions were isolated. One of the isolated protein fractions was able to bind an oligonucleotide in addition to $\mathrm{Zn}$. This oligonucleotide was a DNA fragment of a 
transcription factor of the metallothionein gene (Cousins \& Lee-Ambrose, 1992). These results support the earlier findings of Seguin \& Hamer (1987) that $\mathrm{Zn}$ is involved in regulation of metallothionein gene expression and suggest that this occurs in several tissues.

It is not always easy to distinguish among the catalytic, structural and regulatory functions of $\mathrm{Zn}$. A good illustration is provided by $\mathrm{Zn}$ present in RNA and DNA polymerases. The nature of the function of $\mathrm{Zn}$ in these enzymes may be catalytic by binding substrate, primer or template. Alternatively, $\mathrm{Zn}$ may be involved in maintaining conformation and not be part of the active site of the enzymes. A third possibility is that $\mathrm{Zn}$ acts in a regulatory manner by supplying specificity to proteins involved in gene replication and transcription $(\mathrm{Wu} \& \mathrm{Wu}, 1983)$.

\section{ZINC HOMEOSTASIS}

Homeostasis can be considered effective when the animal is able to maintain optimum health and function (Aggett, 1991). Initially, the animal is able to maintain $\mathrm{Zn}$ homeostasis by varying the rates of $\mathrm{Zn}$ absorption and excretion (Fig. 2). In the short term the animal can further adjust its $\mathrm{Zn}$ status. At low dietary $\mathrm{Zn}$ intakes, redistribution of $\mathrm{Zn}$ occurs to those $\mathrm{Zn}$ pools that are important in metabolism. When dietary $\mathrm{Zn}$ intakes are high, $\mathrm{Zn}$ is sequestered in several body tissues such as liver and bone. Conditions of long term deprivation or excess of dietary $\mathrm{Zn}$ lead to inadequacy of processes involved in maintaining Zn homeostasis (Fig. 2).

The mechanisms which enable the animal to maintain $\mathrm{Zn}$ homeostasis are not exactly understood (Aggett, 1991). This lack of understanding is an important factor contributing to the problems encountered in determining $\mathrm{Zn}$ status.

\section{ASSESSMENT OF ZINC STATUS}

Levels of plasma or serum $\mathrm{Zn}$ and activities of $\mathrm{Zn}$-containing metalloenzymes are frequently measured in studies with man (Prasad et al. 1971). When animals are used, these easily obtainable indicators of $\mathrm{Zn}$ status are of ten supplemented with measurements of $\mathrm{Zn}$ content and $\mathrm{Zn}$ metalloenzyme activities in various tissues (Giugliano \& Millward, 1984). It is questionable, though, whether these indicators are sensitive enough to provide the accuracy required for a reliable interpretation of $\mathrm{Zn}$ status.

Plasma or serum contains only a small proportion of the whole body $\mathrm{Zn}$ content (Jackson, 1989). Moreover, $\mathrm{Zn}$ levels in plasma or serum respond directly to increases in dietary $\mathrm{Zn}$ intake and also to minor catabolic processes occurring in skeletal muscle and other tissues with large $\mathrm{Zn}$ stores.

There are clear effects of dietary $\mathrm{Zn}$ intake on tissue $\mathrm{Zn}$ levels, but they are not uniform among tissues. Feeding diets low in $\mathrm{Zn}$ leads to reductions in $\mathrm{Zn}$ concentrations of the pancreas, liver, kidney, heart, intestine, skin, hair and bones of the $\mathrm{Zn}$ depleted pigs compared with pigs pair-fed diets with National Research Council (1988) recommended levels of Zn (Hoekstra et al. 1956, 1967; Miller et al. 1968; Crofton et al. 1983; Dørup \& Clausen, 1991). Zinc concentrations in skeletal muscle tissue, however, are not affected by dietary Zn levels (Crofton et al. 1983; Dørup \& Clausen, 1991). The large Zn pool found in skeletal muscle appears to be important for the biological functioning of the animal.

The relationship between dietary $\mathrm{Zn}$ intake and tissue $\mathrm{Zn}$ levels was studied by Cousins \& Lee-Ambrose (1992). Following an overnight fast, diets containing different levels of $\mathrm{Zn}$ were administered via a stomach tube to $\mathrm{Zn}$ adequate rats. Two hours after feeding, the largest portion of ${ }^{65} \mathrm{Zn}$ was found in the small intestinal tissue, followed by liver, bone 

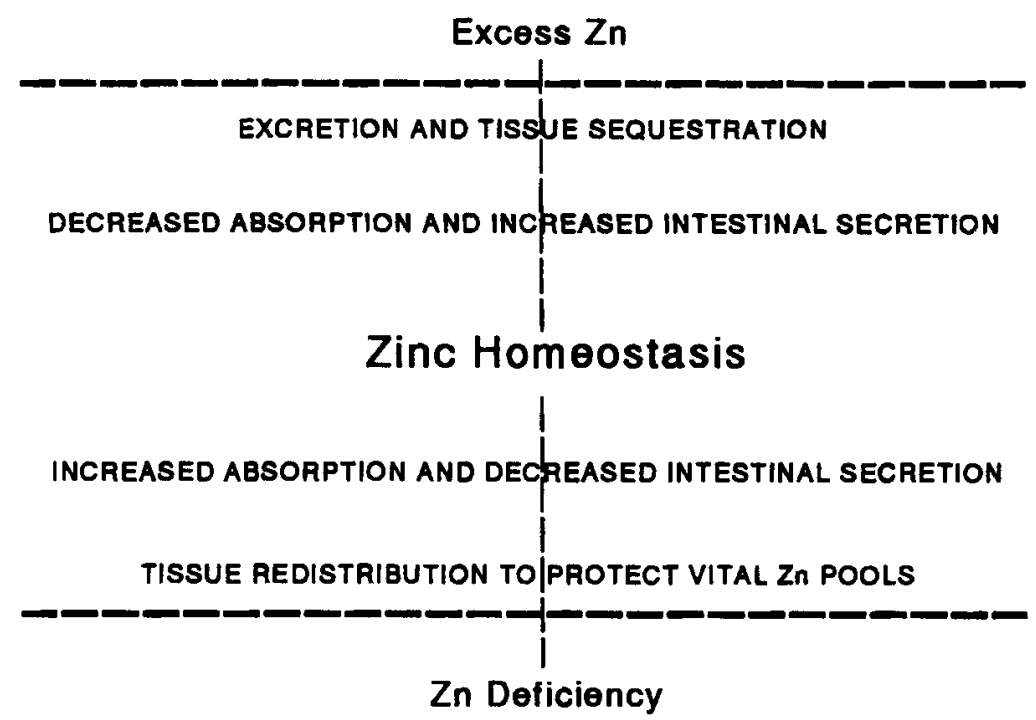

Fig. 2. Adaptive processes used to maintain $\mathrm{Zn}$ homeostasis (Aggett, 1991). During short periods of low or high dietary $\mathrm{Zn}$ intake, animals can initially maintain $\mathrm{Zn}$ homeostasis by adjusting intestinal $\mathrm{Zn}$ absorption and secretion. Other mechanisms that are enacted when intestinal mechanisms become insufficient are redistribution of $\mathrm{Zn}$ to tissues containing functional $\mathrm{Zn}$ pools and sequestration of $\mathrm{Zn}$ in tissues containing exchangeable $\mathrm{Zn}$ pools. During prolonged periods of low or high dietary $\mathrm{Zn}$ intake, animals cannot maintain $\mathrm{Zn}$ homeostasis and show signs of $\mathrm{Zn}$ deficiency and $\mathrm{Zn}$ toxicity respectively.

marrow, bone, skin, kidney, serum, thymus and skeletal muscle (Cousins \& Lee-Ambrose, 1992).

It may be argued that pools which contain $\mathrm{Zn}$ needed for metabolic functions, the functional $\mathrm{Zn}$ pools, are located in those tissues and body fluids least affected by dietary $\mathrm{Zn}$ intake. Tissues that respond strongly to variations in dietary $\mathrm{Zn}$ intake may contain $\mathrm{Zn}$ pools less important for metabolism, the exchangeable $\mathrm{Zn}$ pools. The $\mathrm{Zn}$ content of many tissues and body fluids increases or decreases as dietary $\mathrm{Zn}$ intake changes. This suggests that there are numerous small sized exchangeable $\mathrm{Zn}$ pools.

In clinical nutrition, two approaches have been proposed to identify the early onset of $\mathrm{Zn}$ deficiency. The first involves prediction of exchangeable $\mathrm{Zn}$ pool sizes. This could be done by kinetic modelling studies in which either radioisotopes or the more widely used stable isotopes of $\mathrm{Zn}$ are used. Recently, Fairweather-Tait et al. (1993) demonstrated the feasibility of using an intravenous infusion of ${ }^{70} \mathrm{Zn}$ stable isotope and measuring plasma kinetics to estimate body pool sizes in man. They were able to distinguish between small rapidly exchanging and large slowly exchanging $\mathrm{Zn}$ pools containing less than $10 \mathrm{mg}$ and approximately $350 \mathrm{mg}$ of $\mathrm{Zn}$ respectively. Before this method can be used for assessment of $\mathrm{Zn}$ status, the relative sensitivity of body $\mathrm{Zn}$ pools to dietary and (or) physiological change must be established (Fairweather-Tait et al. 1993).

An alternative approach for identifying the exchangeable $\mathrm{Zn}$ pools is to diagnose factors involved in $\mathrm{Zn}$ redistribution between exchangeable and functional $\mathrm{Zn}$ pools. Some progress has been made in identifying a key factor involved in $\mathrm{Zn}$ redistribution, namely the Zn metalloprotein metallothionein (Golden, 1989). For accurately assessing Zn status in man, King (1990) proposed the use of a combination of plasma levels of $\mathrm{Zn}$ and metallothionein. Low plasma $\mathrm{Zn}$ and low metallothionein levels would indicate depletion of exchangeable $\mathrm{Zn}$ pools as a result of inadequate $\mathrm{Zn}$ intake. On the other hand, low plasma $\mathrm{Zn}$ in combination with high plasma metallothionein levels could be interpreted as 
tissue redistribution of $\mathrm{Zn}$ from exchangeable to functional $\mathrm{Zn}$ pools. Although plasma $\mathrm{Zn}$ is low in both events, the latter condition is not necessarily caused by low dietary $\mathrm{Zn}$ intake (King, 1990). A balanced diet is not available to every human and most of the time there is a lack of information on dietary intake. Consequently, cases of $\mathrm{Zn}$ deficiency are frequently reported (Prasad, 1988), especially if $\mathrm{Zn}$ demands are increased due to growth or pregnancy (Yasodhara et al. 1991). The development of diagnostic tools which allow easy and accurate assessment of $\mathrm{Zn}$ status is essential. Without these indicators, it remains impossible to diagnose cases of $\mathrm{Zn}$ deficiency at an early stage.

In animal nutrition, optimum levels of $\mathrm{Zn}$ have been defined for the different domestic species. The US National Research Council (1979) and the UK Agricultural Research Council (1981) give recommended intakes, and diets are generally formulated accordingly. Therefore, $\mathrm{Zn}$ deficiency is rarely observed in modern livestock production and thus the assessment of $\mathbf{Z n}$ status is not common practice.

\section{BIOLOGICAL ADAPTATIONS DURING ZINC DEFICIENCY}

Experimentally depleted animals have been used to study the biological effects of $\mathrm{Zn}$ deficiency. Early investigations showed that $\mathrm{Zn}$ depletion reduces levels of $\mathrm{Zn}$ and $\mathrm{Zn}$ metalloenzymes in many tissues and body fluids (Hoekstra et al. 1956, 1967; Prasad et al. 1971). More recently, it was found that $\mathrm{Zn}$ deficiency causes increased osmotic fragility of red blood cell membranes (Johanning et al. 1990) and depression in both the humoral and cellular immune responses (Gupta et al. 1985; Verma et al. 1988; Spears et al. 1991).

Of particular interest are the studies investigating the relationships between dietary $\mathrm{Zn}$ intake and growth. Growth retardation observed at low intakes of $\mathrm{Zn}$ can only partly be accounted for by overall depression of feed intake. This was demonstrated by Miller $e t$ al. (1968). In their study, performance was determined for three groups of pigs receiving different amounts of dietary $\mathrm{Zn}$. Pigs fed a $\mathrm{Zn}$ deficient diet had lower gains and poorer feed conversion efficiencies than both pair-fed controls and control pigs with ad lib. access to feed. Feed conversion efficiency was similar in the two control groups (Miller et al. 1968).

Growth retardation of $\mathrm{Zn}$ deficient animals has been associated with reductions in levels of blood insulin-like growth factor I (Cossack, 1986; Dørup et al. 1991), and insulin (Giugliano \& Millward, 1987; Dørup et al. 1991; Droke et al. 1993). Moreover, decreases in serum mitogenic activity and depressions of total pituitary RNA levels and growth hormone mRNA expression were found in pigs fed low dietary levels of $\mathrm{Zn}$ (Swinkels et al. $1994 \mathrm{c}$ ). The observed decreases in both pituitary growth hormone mRNA (Swinkels et al. 1994c) and blood insulin-like growth factor I levels (Cossack, 1986; Dørup et al. 1991; Droke et al. 1993) could not be linked to reduced serum growth hormone levels (Dørup et al. 1991). After injection of a growth hormone-releasing factor analogue, Droke et al. (1993) even observed an increase in serum growth hormone levels in $\mathrm{Zn}$ deficient lambs. Thus, more research is warranted to determine whether synthesis of growth hormone is affected by $\mathrm{Zn}$ deficiency and to identify those growth mechanisms in which $\mathrm{Zn}$ is of critical importance.

In fast growing animals, $\mathrm{Zn}$ deficiency primarily affects protein metabolism. Reduced protein accretion has been found to occur in skeletal muscle, heart, thymus (Giugliano \& Millward, 1987; Dørup \& Clausen, 1991), and small intestinal tissues (Southon et al. 1986) of $\mathrm{Zn}$ deficient animals compared with $\mathrm{Zn}$ adequate controls. A direct association between $\mathrm{Zn}$ metabolism and protein metabolism in tissues like the small intestine may be present.

The magnitude of the effects of $\mathrm{Zn}$ deficiency on metabolism is an indication of the importance of $\mathrm{Zn}$ as a nutrient. The changes in growth, gross anatomy and histology are directly related to inadequate supply of intracellular $\mathrm{Zn}$. Consequently, levels and/or 
activities of $\mathrm{Zn}$ metalloenzymes, $\mathrm{Zn}$ metalloproteins, and $\mathrm{Zn}$ transcription factors are reduced thereby impairing metabolism.

\section{ABSORPTION OF ZINC}

In general, absorption refers to one of the components in nutrient balance studies. More precisely, apparent absorption can be defined as the fraction of the dietary intake that does not appear in the faecal secretions. True absorption corrects the apparent absorption for endogenous losses occurring with intestinal secretions and mucosal sloughing which are not reabsorbed (O'Dell, 1984).

The process of $\mathrm{Zn}$ absorption can be physiologically divided into two separate events: firstly, uptake of $\mathrm{Zn}$ from the lumen into the cell, and secondly $\mathrm{Zn}$ transport from the cell into the circulatory system. In a review, Cousins (1989) has summarized current knowledge on mechanisms suspected to be involved in $\mathrm{Zn}$ uptake and transport (Fig. 3).

Uptake or cellular entry of $\mathrm{Zn}$ appears to occur by means of active transport and facilitated diffusion, both saturable processes (Davies, 1980; Menard \& Cousins, 1983; Blakeborough \& Salter, 1987). A small portion of Zn uptake and transport may be nonsaturable, occurring through simple diffusion (Steel \& Cousins, 1985) and paracellular movement of $\mathrm{Zn}$, i.e. solvent drag (Bronner, 1987). The saturable uptake of $\mathrm{Zn}$ may involve binding of $\mathrm{Zn}$ by low molecular weight ligands which are present within the intestinal lumen. The $\mathrm{Zn}$ ligand complex either enters the cell intact or donates $\mathrm{Zn}$ to a membrane bound receptor. Subsequently, the receptor releases $\mathrm{Zn}$ intracellularly.

The capacity of the small intestine for $\mathrm{Zn}$ transport $\left(V_{\max }\right)$ depends on the body $\mathrm{Zn}$ status. Using isolated intestinal brush border membrane vesicles, Menard \& Cousins (1983) found that $\mathrm{Zn}$ transport in rats fed adequate levels of $\mathrm{Zn}$ was twice as low as in $\mathrm{Zn}$ depleted rats. The affinity for $\mathrm{Zn}\left(K_{\mathrm{m}}\right)$ was not affected by previous dietary $\mathrm{Zn}$ intakes. Thus, the increase in transport rate at low dietary $\mathrm{Zn}$ intakes is due only to an increase in number of receptors for free $\mathrm{Zn}$ or $\mathrm{Zn}$ bound to a low molecular weight ligand.

Evidence presented thus far suggests that $\mathrm{Zn}$ absorption is initiated largely by saturable uptake of $\mathrm{Zn}$ from the intestinal lumen into the cell. Using basolateral membrane vesicles of rat intestine, Oestreicher \& Cousins (1989) studied transport of $\mathrm{Zn}$ out of the cell into the vascular system. Uptake of $\mathrm{Zn}$ in basolateral membrane vesicles was saturable and not affected by dietary $\mathrm{Zn}$ intake (Oestreicher \& Cousins, 1989). A saturable Zn uptake indicates that a carrier mediated mechanism exists for $\mathrm{Zn}$ to enter the blood circulation. The lack of effect of dietary $\mathrm{Zn}$ intake on vesicular $\mathrm{Zn}$ uptake further suggests that $\mathrm{Zn}$ absorption is not regulated at the basolateral membrane (Oestreicher \& Cousins, 1989).

\section{ROLE OF INTESTINAL METALLOTHIONEIN IN ZINC ABSORPTION}

Metallothionein is a protein of low molecular weight, about $6500 \mathrm{D}$, with a high metalbinding capacity, 7-10 atoms/mole (Bremner, 1983). For a thorough review of the role of metallothionein in $\mathrm{Zn}$ metabolism the reader is referred to Bremner (1983), Cousins (1985), Richards (1989) and Bremner \& Beattie (1990).

A regulatory role of intestinal metallothionein in $\mathrm{Zn}$ absorption was first proposed by Richards \& Cousins (1975). Intestinal metallothionein is synthesized in proportion to dietary Zn intake (Cousins \& Lee-Ambrose, 1992). Metallothionein reduces Zn absorption by sequestering $\mathrm{Zn}$ within the enterocyte due to its higher affinity for $\mathrm{Zn}$ compared with other identified intestinal proteins (Starcher et al. 1980; Menard et al. 1981). 


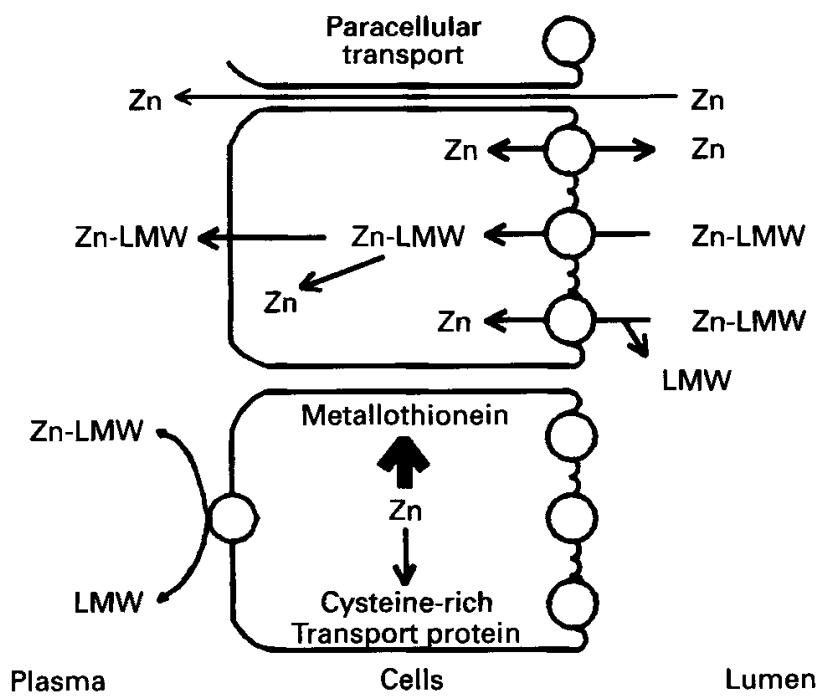

Fig. 3. A model for zinc absorption (Cousins, 1989; Hempe \& Cousins, 1992). Zinc absorption can be physiologically divided into two processes: uptake of $\mathrm{Zn}$ from the GI lumen into the enterocyte (top) and transport of $\mathrm{Zn}$ from the enterocyte into the circulatory system (bottom). Within the GI lumen $\mathrm{Zn}$ may be presented for uptake into the enterocyte as free $\mathrm{Zn}$ or as $\mathrm{Zn}$ bound to a low molecular weight (LMW) ligand. The uptake of free $\mathrm{Zn}$ or $\mathrm{Zn}-\mathrm{LMW}$ may involve carrier mediated and non-mediated mechanisms (top). Within the enterocyte, $\mathrm{Zn}$ transport may involve a cysteine-rich transcellular transport protein. Metallothionein competes for $\mathrm{Zn}$ with the transcellular transport protein and, therefore, may play a regulatory role in $\mathrm{Zn}$ absorption. Export of $\mathrm{Zn}$ from the enterocyte into the circulatory system may involve active mechanisms (bottom). A small portion of $\mathrm{Zn}$ uptake and transport may occur through simple diffusion and paracellular transport of free $\mathrm{Zn}$ (top).

As shown in Fig. 3, Hempe \& Cousins (1992) included an interaction of a cysteine-rich intestinal protein, identified by Hempe \& Cousins in 1989, with metallothionein in the $\mathrm{Zn}$ absorption model proposed by Cousins (1989). The cysteine-rich protein may enhance $\mathrm{Zn}$ absorption by transporting $\mathrm{Zn}$ transcellularly, from the intestinal brush border to the basolateral membrane. Intestinal metallothionein competitively inhibits binding of $\mathrm{Zn}$ to the transport protein and thereby regulates $\mathrm{Zn}$ absorption (Hempe \& Cousins, 1992).

The regulatory role of intestinal metallothionein in $\mathrm{Zn}$ absorption has been partly challenged by Flanagan et al. (1983) and Coppen \& Davies (1987). In these studies, criticism was focused on the proportional response of intestinal metallothionein synthesis to dietary $\mathrm{Zn}$ levels. Flanagan et al. (1983) observed only a transitory effect of dietary $\mathrm{Zn}$ level on intestinal metallothionein synthesis. They concluded that intestinal metallothionein synthesis was most likely induced by the nutritional stress associated with $\mathrm{Zn}$ deficiency and not by dietary $\mathrm{Zn}$ level (Flanagan et al. 1983). Moreover, Coppen \& Davies (1987) found that dietary $\mathrm{Zn}$ intake did induce intestinal metallothionein synthesis in rats, but only at $\mathrm{Zn}$ levels of 5 to $80 \mathrm{mg}$ per $\mathrm{kg}$ diet. At higher levels of $\mathrm{Zn}, 80$ to $160 \mathrm{mg}$ per $\mathrm{kg}$ diet, no further induction of intestinal metallothionein was observed (Coppen \& Davies, 1987).

\section{SITE(S) OF ZINC ABSORPTION}

Many researchers have investigated the capacity for $\mathrm{Zn}$ absorption of various sites of the gut using a variety of methods. Some have reported that net $\mathrm{Zn}$ absorption in rats occurs primarily in the small intestine (Underwood, 1977) with negligible $\mathrm{Zn}$ absorption occurring 
Table 2. Apparent absorption coefficients of $Z n$ determined within seven gut segments of depleted pigs fed an isolated soya protein semipurified $Z n$ depletion diet supplemented with 15 and 45 p.p.m. $\mathrm{Zn}$ as $\mathrm{ZnSO}{ }_{4}{ }^{a}$

\begin{tabular}{|c|c|c|c|}
\hline gut segment $t^{\text {be }}$ & 15 p.p.m. $\mathrm{ZnSO}_{4}$ & 45 p.p.m. $\mathrm{ZnSO}_{4}$ & SEM \\
\hline & $\%$ & $\%$ & \\
\hline Stomach & $-20 \cdot 4$ & $-16-1$ & 6.6 \\
\hline \multicolumn{4}{|l|}{ Small intestine } \\
\hline Proximal & $-24 \cdot 3$ & $-46 \cdot 9$ & $18 \cdot 7$ \\
\hline Medial & $5 \cdot 4$ & 0.7 & $14 \cdot 1$ \\
\hline Distal & $25 \cdot 5$ & $17 \cdot 6$ & 5.8 \\
\hline \multicolumn{4}{|l|}{ Large intestine } \\
\hline Caecum & $18 \cdot 0$ & $18 \cdot 4$ & 4.7 \\
\hline \multicolumn{4}{|l|}{ Colon } \\
\hline Proximal & $20 \cdot 3$ & $15 \cdot 7$ & 4.9 \\
\hline Distal & $16 \cdot 7$ & $17 \cdot 4$ & $6 \cdot 2$ \\
\hline
\end{tabular}

${ }^{a}$ Apparent absorption coefficients were determined using the indirect indicator $\left(0.25 \% \mathrm{Cr}_{2} \mathrm{O}_{3}\right)$ method. Each depleted mean represents five pigs that had been depleted for a 32-d period using an isolated soyabean semipurified diet containing 17 p.p.m. Zn. Pigs were killed $0,3,6,12$ and $24 \mathrm{~d}$ (one pig per d) after the start of a $24 \mathrm{~d} \mathrm{Zn}$ repletion period. Digesta were collected exactly $2.5 \mathrm{~h}$ after feeding the last meal using a total digesta collection procedure. The gut was divided into seven segments: stomach, three small intestinal segments of equal length, caecum and two colonic segments of equal length.

${ }^{b}$ Linear, quadratic and cubic increases from stomach to distal colon segment $(P<0.05)$.

$\mathrm{Zn}$ level by gut segment interaction $(P<0 \cdot 01)$.

in other segments of the gut (Underwood, 1977; Davies, 1980). Others, however, did observe substantial $\mathrm{Zn}$ absorption in the large intestine of rats (Wapnir et al. 1985; Seal \& Mathers, 1989), pigs (Partridge, 1978), sheep (Grace, 1975) and cattle (Bertoni et al. 1976). Furthermore, absorption of $\mathrm{Zn}$ anterior to the small intestine was observed in chickens (Miller \& Jensen, 1966) and dairy cattle (Miller \& Cragle, 1965).

Duodenal and ileal segments of the small intestine have been suggested as primary sites for $\mathrm{Zn}$ absorption. Infusion of ${ }^{65} \mathrm{Zn}$ into a ligated duodenal loop led to the highest ${ }^{85} \mathrm{Zn}$ recovery in blood, liver, kidneys and heart (Van Campen \& Mitchell, 1965) or the whole body (Davies, 1980). With the use of an in vivo intestinal perfusion technique, it was found that the ileum had the highest capacity for $\mathrm{Zn}$ absorption (Antonson et al. 1979). Recently, Swinkels et al. (1994b) determined the site of apparent $\mathrm{Zn}$ absorption using a total digesta collection procedure and the indirect indicator method. The pigs used in this study had been depleted of $\mathrm{Zn}$ for a 5-week period by feeding an isolated soya protein semipurified diet. The diet contained 17 p.p.m. $\mathrm{Zn}$ and $3 \%$ cellulose. Following the depletion period, pigs were repleted by feeding the same diet supplemented with either 15 or 45 p.p.m. $\mathrm{Zn}$ as $\mathrm{ZnSO}_{4}$. As shown in Table 2, jejunal and ileal segments of the small intestine were identified as the main sites of $\mathrm{Zn}$ absorption. The large intestine did not seem to contribute to the overall apparent $\mathrm{Zn}$ absorption (Swinkels et al. 1994b).

Partridge (1978) and Seal \& Mathers (1989) examined the role of different amounts and sources of dietary fibre or non-starch polysaccharides on capacity and site of apparent $\mathrm{Zn}$ absorption. Using re-entrant cannulas in $\mathrm{Zn}$ adequate pigs given a casein semipurified diet containing about 50 p.p.m. $\mathrm{Zn}$ as $\mathrm{ZnCO}_{3}$ and $3 \%$ cellulose, Partridge (1978) found that the large intestine was the primary site of $\mathrm{Zn}$ absorption. However, the gut sites anterior to the terminal ileum became the more important sites of apparent $\mathrm{Zn}$ absorption when $9 \%$ instead of $3 \%$ cellulose was included in the diet. The inclusion of a high level of cellulose in the diet also decreased overall apparent $\mathrm{Zn}$ absorption (Partridge, 1978). Feeding 
different non-starch polysaccharide sources to rats, Seal \& Mathers (1989) found similar rates of $\mathrm{Zn}$ absorption from everted gut sacs of duodenal, ileal and colonic segments. Analysis of the everted gut sacs showed that the absorbed $\mathrm{Zn}$ was largely accumulated in all intestinal tissues, particularly in the duodenal segment, and that only a small amount of $\mathrm{Zn}$ was transferred across the serosal surface. The source of non-starch polysaccharides in the diet appeared to affect the capacity of the large intestine for $\mathrm{Zn}$ absorption. Rats previously fed diets containing high levels of pectin showed higher rates of $\mathrm{Zn}$ transfer by colonic tissues than rats previously fed diets with or without non-starch polysaccharides from wheat bran (Seal \& Mathers, 1989).

From the above mentioned studies it appears that all segments of the gut have the capacity to absorb $\mathrm{Zn}$. As stated by Seal \& Mathers (1989), some of the differences observed among the studies may relate to experimental technique, animal species and dietary composition. With regard to the diet, it appears that the capacity of the large intestine to absorb $\mathrm{Zn}$ is expressed when a fibre or non-starch polysaccharide source is included in the diet (Grace, 1975; Bertoni et al. 1976; Partridge, 1978; Seal \& Mathers, 1989). However, inclusion of high amounts of dietary fibre or non-starch polysaccharide (Partridge, 1978) or a high body need for $\mathrm{Zn}$ in the experimental animals (Swinkels et al. 1994b) appeared to increase the relative contribution of the small intestine to overall $\mathrm{Zn}$ absorption.

\section{MINERALS INTERACTING WITH ZINC DURING ABSORPTION}

Transport of $\mathrm{Zn}$ from the intestinal lumen into the enterocyte can be impeded by other minerals. Iron and $\mathrm{Cd}$ have been shown to inhibit $\mathrm{Zn}$ uptake from an open-ended duodenal loop in Fe deficient mice (Hamilton et al. 1978). An interaction between $\mathrm{Zn}$ and Fe was also observed from jejunal segments of $\mathrm{Fe}$ adequate rats. Addition of $\mathrm{Zn}$ to the perfusate reduced absorption of Fe by $34 \%$ (El-Shobaki \& Srour, 1989). Substantial inhibition exerted by $\mathrm{Fe}$ on $\mathrm{Zn}$ absorption in men was reported by Solomons \& Jacob (1981). The inhibition became more apparent with increasing ratios of dietary $\mathrm{Fe}$ to $\mathrm{Zn}$. In a subsequent study, it was shown that there is a competition between $\mathrm{Fe}$ and $\mathrm{Zn}$ at intraluminal and intracellular sites (Solomons et al. 1983).

Copper uptake by intestinal brush border membrane vesicles of rats given either high levels of $\mathrm{Zn}$, adequate $\mathrm{Cu}$ and $\mathrm{Zn}$, or $\mathrm{Cu}$ deficient diets was studied by Fischer \& L'Abbe (1985). They observed the highest $\mathrm{Cu}$ uptake by vesicles of rats given high levels of $\mathrm{Zn}$ (Fischer \& L'Abbe, 1985). In pigs given a high dietary level of $\mathrm{Cu}$, an increase in plasma $\mathrm{Cu}$ and in liver $\mathrm{Cu}$ and $\mathrm{Zn}$ contents was observed together with a concurrent decrease in plasma and liver Fe (Shurson et al. 1990). A tissue specific association between $\mathrm{Zn}$ and $\mathrm{Cu}$ was found by Swinkels et al. (1994a). In their Zn depletion-repletion study, they examined the bioavailability of $\mathrm{Zn}$ from different $\mathrm{Zn}$ sources by determining the $\mathrm{Zn}$ contents in liver, kidney, pancreas, brain and gut tissues. In the kidney, $\mathrm{Cu}$ was depleted and replaced with $\mathrm{Zn}$, whereas kidney $\mathrm{Fe}$ levels and both $\mathrm{Cu}$ and $\mathrm{Fe}$ levels in other tissues were not affected by the tissue Zn status (Swinkels et al. 1994a).

Zinc retention was not different in pigs fed different levels of Ca (Morgan et al. 1969). In rats, a negative effect of $\mathrm{Zn}$ on $\mathrm{Ca}$ uptake by intestinal brush border membrane vesicles was only observed at high $\mathrm{Zn}$ to $\mathrm{Ca}$ ratios (Roth-Bassell \& Clydesdale, 1991).

It has become clear that the presence of $\mathrm{Cu}$ and $\mathrm{Fe}$ in the chyme can affect $\mathrm{Zn}$ absorption. It is not clear whether both minerals actually interfere with cellular uptake of $\mathrm{Zn}$ or whether $\mathrm{Cu}$ and $\mathrm{Fe}$ interact with $\mathrm{Zn}$ to form non-absorbable complexes within the lumen of the gut. Interference with cellular uptake may occur when the minerals compete either for common transporters in the cell membrane or for common cytosolic proteins that are involved in 
intracellular transport of $\mathrm{Zn}$. The interaction between $\mathrm{Cu}$ and $\mathrm{Zn}$ may result from competition for binding with metallothionein. Metallothionein has a high affinity for both $\mathrm{Cu}$ and $\mathrm{Zn}$ (Cousins, 1985), but thermodynamically binding with $\mathrm{Cu}$ is preferred to binding with Zn (Williams, 1984).

\section{INTRINSIC FACTORS AFFECTING ZINC ABSORPTION}

Zinc absorption is affected by dietary and endogenous factors. In rat jejunal segments, an excess of unhydrolysed glucose polymers and slowly absorbed sugars reduces $\mathrm{Zn}$ absorption (Wapnir et al. 1989). Absorption of $\mathrm{Zn}$ is also affected by the protein source (Miller \& Jensen, 1966; O'Dell et al. 1972) as well as the protein concentration (Hunt \& Larson, 1990; Hunt \& Johnson, 1992).

The negative association of protein with $\mathrm{Zn}$ absorption may be due to other dietary components that contaminate the protein source. An allegedly higher $\mathrm{Zn}$ absorption from diets containing an animal protein source compared with diets based on cereal protein proved to be due to the presence of phytate in the cereal protein sources (Harmuth-Hoene \& Meuser, 1987). Phytate and also fibre are two well known intrinsic factors which have been shown to affect the absorption of $\mathrm{Zn}$ negatively (Davies \& Reid, 1979; Simons et al. 1990).

Endogenous factors may also interfere with $\mathrm{Zn}$ absorption from the gut lumen. A decrease in the plasma $\mathrm{Zn}$ level was observed by Sturniolo et al. (1991) after selective inhibition of gastric acid secretion in man. Their explanation was that a more alkaline environment in the stomach induces the formation of insoluble $\mathrm{Zn}$ compounds which cannot be absorbed further down the gut (Sturniolo et al. 1991).

As shown in the above mentioned studies both dietary and endogenous factors may affect the absorption of $\mathrm{Zn}$ to some extent but, unless dietary $\mathrm{Zn}$ intake is too low or too high for a prolonged period, the animal will be able to maintain $\mathrm{Zn}$ homeostasis.

\section{BIOLOGICAL VALUE OF DIETARY COMPLEXES AND CHELATES OF ZINC}

\section{METAL COMPLEXES AND CHELATES}

Metal complexes are compounds of a central metal atom together with ligands which contain at least one ligand atom with a free electron pair. Proteins and carbohydrates including their derivatives, lipids, and many synthetic compounds which contain an $\mathrm{O}, \mathrm{S}$ or $\mathrm{N}$ atom may function as ligand (Kratzer \& Vohra, 1986). The number of ligands that bind the metal atom usually exceeds the number expected from valency considerations (Smith, 1990). Binding of the ligand to the metal occurs through donation of the free electron pair of the ligand atom to the metal atom which acts as an electron acceptor (Fig. 4). This type of bond is referred to as a coordinate or dative bond. Coordinate bonds are mostly formed between the transitional elements and the electronegative atoms oxygen, sulphur and nitrogen (Kratzer \& Vohra, 1986).

A metal chelate is a special form of a metal complex. A metal complex is considered a metal chelate when instead of one ligand atom, two or more atoms of the ligand donate their electron pairs to the metal in the formation of coordinate bonds. The chemical ring structure formed between the ligand and the metal resembles a pincer-like claw, for which the Greek word is 'Chelè' (Fig. 4). Formation of metal complexes and chelates are both reversible processes. A continuous exchange of ligands occurs with a change in intraluminal or intracellular conditions. The free metal prefers those ligands with which it can form the 
Zn Complexes

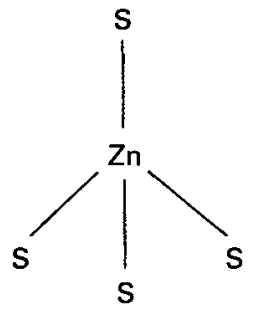

Zn Chelate

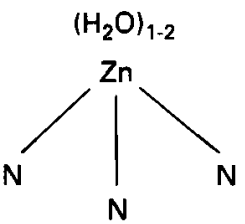

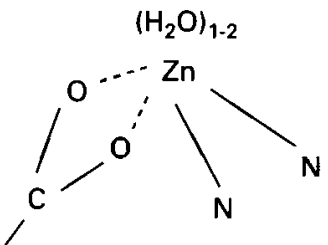

Fig. 4. Complexes and chelates of zinc as found at some known $\mathrm{Zn}$ sites of $\mathrm{Zn}$-containing proteins (Williams, 1984). In $\mathrm{Zn}$ complexes only one atom of each participating ligand donates its free electron pair to $\mathrm{Zn}$. this occurs at the structure sites of metallothionein (shown in part) and alcohol dehydrogenase (left figure) and at the active site of carbonic anhydrase (centre figure). In $\mathrm{Zn}$ chelates two or more atoms of each participating ligand donate their free electron pairs to $\mathrm{Zn}$. This occurs at the active site of carboxypeptidases (right figure).

chemically most stable complexes or chelates under the given conditions (Kratzer \& Vohra, 1986).

\section{CONSIDERATIONS WHEN DETERMINING BIOAVAILABILITY OF ZINC}

The term 'bioavailability' is generally used to describe the properties of absorption and utilization of nutrients (O'Dell, 1984). Only absorbed nutrients which can participate in the biological processes in the animal are considered utilizable, and thus bioavailable. Free $\mathrm{Zn}$ or $\mathrm{Zn}$ bound to low molecular weight ligands could have been absorbed and be present in body fluids and tissues, but it may not have been utilized. In determining the $\mathrm{Zn}$ availability of mineral sources, therefore, $\mathrm{Zn}$ metalloenzyme activities and metallothionein levels in body fluids and tissues are probably more reliable indicators of $\mathrm{Zn}$ availability than blood or tissue $\mathrm{Zn}$ concentrations.

A second important consideration in $\mathrm{Zn}$ availability studies is that animals maintain homeostasis by secreting part of the excess body $\mathrm{Zn}$ into the gut lumen. To prevent this mechanism from occurring, the animals should be depleted of $\mathrm{Zn}$ prior to the study. In a study conducted by Hallmans et al. (1987), bioavailability of $\mathrm{Zn}$ from one test food was estimated using two groups of rats with different needs for $\mathrm{Zn}$ to maintain $\mathrm{Zn}$ homeostasis. To increase the need for $\mathrm{Zn}$ in rats of the treatment group, anabolic processes that require $\mathrm{Zn}$ were stimulated by an intraperitoneal injection of a solution containing amino acids. The controls were injected with physiological saline. Results of the study showed that rats receiving the amino acid solution had a $40 \%$ increase in $\mathrm{Zn}$ absorption from the test food (Hallmans et al. 1987).

In addition to the use of animals with a high body need for $\mathrm{Zn}$, the level of $\mathrm{Zn}$ used to replete the animals with $\mathrm{Zn}$ has to be carefully selected. If the levels of $\mathrm{Zn}$ are too low, the appetite of the depleted animals may remain depressed. On the other hand, if levels of $\mathrm{Zn}$ are too high, repletion of the depleted tissues with $\mathrm{Zn}$ may occur very rapidly. In both cases, the availability of $\mathrm{Zn}$ from the experimental diets cannot be determined. Thus, a dose response experiment has to be conducted to determine an optimum level of $\mathrm{Zn}$. With an optimum $\mathrm{Zn}$ level, the change in $\mathrm{Zn}$ status of the depleted animal can be monitored over time as an indication of $\mathrm{Zn}$ availability in the experimental diets. Effectiveness and duration of $\mathrm{Zn}$ repletion can be determined by monitoring performance, repetitive measurement of serum or plasma $\mathrm{Zn}$ or metallothionein levels, the activities of metalloenzymes and serum 
mitogenic activity (Miller et al. 1968; Prasad et al. 1971; Swinkels et al. 1994a). Moreover, tissue levels of $\mathrm{Zn}$ and $\mathrm{Zn}$ metalloenzyme activities can be determined at one or more times during $\mathrm{Zn}$ repletion. Each of these measurements or several of them together may be referred to as a $\mathrm{Zn}$ bioassay (Wedekind \& Baker, 1990).

A final consideration in mineral availability studies is that the mineral source used as the control may influence the outcome of the comparison. For example, based on tibia $\mathrm{Zn}$, Wedekind \& Baker (1990) estimated a $61 \%$ availability of $\mathrm{Zn}$ from $\mathrm{ZnO}$ relative to $\mathrm{ZnSO}_{4}$. Both inorganic $\mathrm{Zn}$ sources are frequently used as control treatments in $\mathrm{Zn}$ bioassays.

\section{AVAILABILITY OF ZINC COMPLEXED WITH PICOLINIC ACID}

Picolinic acid (pyridine 2-carboxylic acid), a minor metabolite of tryptophan, was one of the first organic ligands studied for its possible promoting effect on $\mathrm{Zn}$ availability. The interest in picolinic acid originated from the finding that human milk provides more available Zn than cows' milk. In this research, Evans \& Johnson (1979) characterized picolinic acid as a strong $\mathrm{Zn}$ binding ligand in human milk.

In subsequent studies, Evans \& Johnson $(1980 a-c)$ showed that absorption of Zn was increased and growth rate stimulated in rats given diets supplemented with picolinic acid. In the later studies of Roth \& Kirchgessner (1985) and Hill et al. (1986) these findings were not confirmed. Addition of picolinic acid to the diet improved neither the body gains, serum $\mathrm{Zn}$ levels, and $\mathrm{Zn}$ contents in the testes, femur and whole body of rats (Roth \& Kirchgessner, 1985) nor bone Zn concentrations in pigs (Hill et al. 1986).

Using everted sacs of rat duodenum and ileum, Seal \& Heaton (1983) studied the uptake of $\mathrm{Zn}$ with a variety of ligands including 2-picolinic and 4-picolinic acid. Salient features of this study are presented in Fig. 5. Adding 2-picolinic acid to the mixture improved the uptake of $\mathrm{Zn}$ in both everted duodenal and ileal sacs when compared with inorganic sulphate. Of the organic ligands tested, sulphate proved to be the most effective in enhancing $\mathrm{Zn}$ uptake. Compared to sulphate, the amino acids histidine and cysteine did improve $\mathrm{Zn}$ uptake from the ileal but not from the duodenal sac (Seal \& Heaton, 1983). As part of the same study, the most promising ligands were included in the diets of intact rats housed in metabolism cages. The ligand 2-picolinic acid did improve apparent $\mathrm{Zn}$ absorption as expected from the results of the in vitro study. Zinc retention, however, was not improved primarily because of increased urinary Zn excretion (Seal \& Heaton, 1983). These findings suggest that $\mathrm{Zn}$ was so tightly bound to 2-picolinic acid that it could not be utilized after being absorbed in complexed form, and therefore was excreted via the kidneys (Seal \& Heaton, 1985).

\section{AVAILABILITY OF ZINC COMPLEXED WITH METHIONINE OR OTHER AMINO ACIDS}

Amino acids are frequently used as dietary ligands for synthesizing $\mathrm{Zn}$ complexes or chelates. Of all $\mathrm{Zn}$ amino acid complexes studied $\mathrm{Zn}$ methionine has received by far the most attention.

An improvement in $\mathrm{Zn}$ availability from the complex $\mathrm{Zn}$ methionine compared with $\mathrm{ZnSO}_{4}$ was observed after measuring levels of $\mathrm{Zn}$ in the tibia of chicks (Wedekind et al. 1992). In other studies, $\mathrm{Zn}$ availability from $\mathrm{Zn}$ methionine, determined by measuring performance and serum $\mathrm{Zn}$ levels, was not different from an inorganic $\mathrm{Zn}$ salt in pigs (Kornegay \& Thomas, 1975; Hill et al. 1986) or in heifers (Spears, 1989). Although apparent $\mathrm{Zn}$ absorption from $\mathrm{Zn}$ methionine was not different from $\mathrm{ZnO}$, Spears (1989) did observe an increase in $\mathrm{Zn}$ retention of lambs fed $\mathrm{Zn}$ methionine. The increase in $\mathrm{Zn}$ 

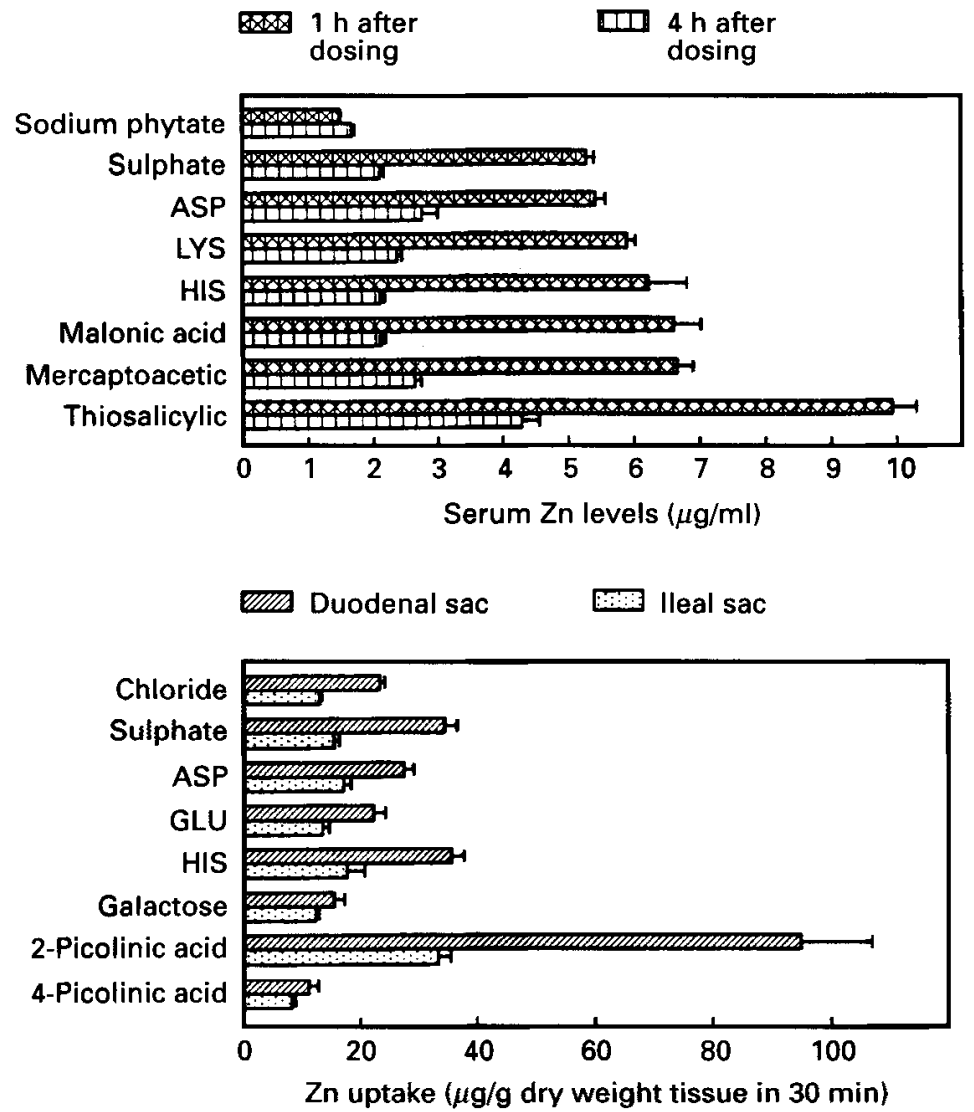

Fig. 5. Effect of inorganic and organic ligands on serum Zn concentrations and intestinal Zn uptake in rats. Serum $\mathrm{Zn}$ levels (top) were measured in rats 1 and $4 \mathrm{~h}$ after oral dosage of $\mathrm{ZnSO}_{4}$ or mixtures of $\mathrm{ZnCl}_{2}$ and different organic ligands containing 10 p.p.m. Zn (Giroux \& Prakash, 1977). Intestinal $\mathrm{Zn}$ uptake (bottom) was measured using duodenal and ileal everted gut sacs after incubating with a buffer containing $0.0003 \mathrm{M}-\mathrm{Zn}$ as $\mathrm{ZnCl}_{2}, \mathrm{ZnSO}_{4}$ or mixtures of $\mathrm{ZnCl}_{2}$ and organic ligands (Seal \& Heaton, 1983). Organic ligands containing negatively charged carboxyl or thiol groups appeared to be the most effective in stimulating serum $\mathrm{Zn}$ concentrations and intestinal $\mathrm{Zn}$ uptake.

retention was caused by a slight reduction in urinary $\mathrm{Zn}$ excretion. A higher $\mathrm{Zn}$ retention with no difference in apparent $\mathrm{Zn}$ absorption (Spears, 1989) suggests that the complex $\mathrm{Zn}$ methionine provided more utilizable $\mathrm{Zn}$ than $\mathrm{ZnO}$. In a 2-year study with beef cows and calves, Spears \& Kegley (1991) observed a slight improvement in over-all performance with the use of $\mathrm{Zn}$ methionine and $\mathrm{Mn}$ methionine compared with $\mathrm{ZnO}$ and $\mathrm{MnO}$. Addition of $\mathrm{Zn}$ methionine instead of $\mathrm{ZnO}$ to chick diets containing already adequate amounts of $\mathrm{Zn}$ slightly increased the content of $\mathrm{Zn}$ in the pancreas (Pimentel et al. 1991). Growth and concentrations of $\mathrm{Zn}$ in tibiotarsus and liver were not affected by the $\mathrm{Zn}$ source (Pimentel et al. 1991). Carcass quality of steers was improved with a $\mathrm{Zn}$ methionine supplement to the diet instead of $\mathrm{ZnO}$ (Greene et al. 1988). The better carcass quality was not associated with improved performance.

The influence of a variety of amino acids and their chemical homologues on $\mathrm{Zn}$ uptake from perfused jejunal, ileal and colonic segments of rats was studied by Wapnir \& Stiel (1986). In the small intestine, perfusion with tryptophan, histidine, cysteine and proline achieved a higher $\mathrm{Zn}$ uptake compared with results after perfusion with their respective 
homologues tryptophol, imidazole, $N$-acetyl-L-cysteine and pyroglutamate. It appeared that both mediated and non-mediated transport mechanisms were involved in $\mathrm{Zn}$ uptake of the small intestine when the perfusate contained one of the amino acids. When the perfusate contained one of the amino acid homologues only non-mediated transport mechanisms appeared to be activated. In the colon, uptake of $\mathrm{Zn}$ was increased only with imidazole, the homologue of histidine, which may be explained by the high structural affinity of imidazole for $\mathrm{Zn}$ (Wapnir \& Stiel, 1986). In humans, a $25 \%$ increase in serum $\mathrm{Zn}$ level was observed after ingestion of $\mathrm{Zn}$ as a $\mathrm{Zn}$ histidine complex compared with $\mathrm{ZnSO}_{4}$ (Schölmerich et al. 1987). The apparent higher absorption of $\mathrm{Zn}$ histidine, however, was associated with increased urinary $\mathrm{Zn}$ excretion. Performance of grower pigs was not improved by supplementing $\mathrm{Zn}$ adequate diets with $1 \%$ histidine or 289 p.p.m. EDTA (Dahmer et al. 1972; Owen et al. 1973). However, inclusion of histidine appeared to alleviate skin lesions of the $\mathrm{Zn}$ deficient pigs used by Dahmer et al. (1972). This may indicate that dietary histidine did improve $\mathrm{Zn}$ availability. Alternatively, histidine may have stimulated the healing process independent of $\mathrm{Zn}$. After measuring several serum and tissue variables in pigs that had been depleted of $\mathrm{Zn}$, Swinkels et al. (1994a) reported similar availabilities of $\mathrm{Zn}$ from an amino acid chelate and $\mathrm{ZnSO}_{4}$. However, the apparent $\mathrm{Zn}$ absorption coefficients were not consistent with the serum and tissue $\mathrm{Zn}$ measurements (Swinkels et al. 1994b).

Uptake, mucosal retention and absorption of $\mathrm{Zn}$ from $\mathrm{ZnCl}_{2}, \mathrm{ZnCl}_{2}$ with methionine, $\mathrm{Zn}$ complexes with methionine and $\mathrm{ZnCl}_{2}$ with EDTA were studied by Hempe \& Cousins (1989) with the aid of ligated rat duodenal loops. After $60 \mathrm{~min}$ incubation, Zn uptake and absorption were lowest for $\mathrm{Zn}$ methionine and the $\mathrm{Zn}$ EDTA mixture. It was suggested that the low $\mathrm{Zn}$ absorption was associated with reduced binding of $\mathrm{Zn}$ to an unidentified low molecular weight protein present in the mucosa (Hempe \& Cousins, 1989). Later on, the protein was assigned a possible role in the transcellular transport of $\mathrm{Zn}$ as shown in Fig. 3. Uptake of $\mathrm{Zn}$, determined with everted duodenal sacs of pigs, was not different among $\mathrm{ZnSO}_{4}$, $\mathrm{Zn}$ methionine and $\mathrm{Zn}$ lysine (Hill et al. 1987).

The hypothesis that organic ligands are actively involved in $\mathrm{Zn}$ absorption was examined by Giroux \& Prakash (1977). Salient features of the results of this study are shown in Fig. 5. In their study, Giroux \& Prakash (1977) gave different ligand and $\mathrm{ZnSO}_{4}$ mixtures ( 10 p.p.m. $\mathrm{Zn}$ ) by stomach tube after a $24 \mathrm{~h}$ fast. One and $4 \mathrm{~h}$ after force feeding the rats, they determined $\mathrm{Zn}$ absorption by measuring serum $\mathrm{Zn}$ levels. As shown in Fig. 5, ligands containing thiol and carboxylic acid groups, such that formation of five- or six-membered $\mathrm{Zn}$ chelates could occur, proved to be the most effective in increasing levels of serum $\mathrm{Zn}$ $1 \mathrm{~h}$ after feeding. A 1:1 mixture of phytate and $\mathrm{ZnSO}_{4}$ reduced serum $\mathrm{Zn}$ levels about 3.5 times compared with the control $\mathrm{ZnSO}_{4}$. Of the amino acids tested, a 2:1 mixture of glycine and $\mathrm{ZnSO}_{4}$ was most effective. Increases in serum $\mathrm{Zn}$ levels observed with the amino acids lysine, histidine and cysteine were only slightly lower. Serum $\mathrm{Zn}$ levels, measured $4 \mathrm{~h}$ after feeding, returned to the $\mathrm{ZnSO}_{4}$ control value for most amino acid and $\mathrm{ZnSO}_{4}$ mixtures. In contrast to the amino acid ligands, changes in levels of serum $\mathrm{Zn}$ observed with phytate and several ligands containing thiol or carboxylic acid groups $1 \mathrm{~h}$ after feeding were still maintained $4 \mathrm{~h}$ after feeding (Giroux \& Prakash, 1977). Also, in the study of Seal \& Heaton (1983), a ligand containing a carboxylic acid group, 2-picolinic acid, improved the uptake of $\mathrm{Zn}$ when compared with inorganic sulphate (Fig. 5).

It is difficult to deduce a general mode of action for absorption of organic $\mathrm{Zn}$ complexes or chelates from the studies of Giroux \& Prakash (1977) and Seal \& Heaton (1983). In both studies it appears, however, that absorption of $\mathrm{Zn}$ may be enhanced in the presence of organic ligands containing highly negatively charged atom groups that form negatively charged $\mathrm{Zn}$ complexes or chelates. This observation is supported by the findings of Tacnet 
et al. (1990) in a study using intestinal membrane vesicles of rats. They also found a considerable increase in vesicular $\mathrm{Zn}$ uptake when $\mathrm{ZnSO}_{4}$ was substituted for $\mathrm{Zn}(\mathrm{SCN})_{4}{ }^{2-}$, a highly negatively charged anion.

\section{CONCLUSIONS}

Studies on the mechanisms underlying $\mathrm{Zn}$ absorption have suggested that $\mathrm{Zn}$ may be absorbed as part of an intact complex or chelate formed between $\mathrm{Zn}$ and one or more organic ligands. To date, this hypothesis has been examined primarily using Zn complexed to either picolinate or methionine. Although both organic $\mathrm{Zn}$ forms have been shown to affect $\mathrm{Zn}$ absorption, a consistent improvement in availability of $\mathrm{Zn}$ from these sources was not found. More basic research focusing on conditions within the gut lumen and on mechanisms underlying $\mathrm{Zn}$ absorption is needed to elucidate which characteristics of a dietary $\mathrm{Zn}$ form are essential in determining its biological value. Within the gut lumen, dietary $\mathrm{Zn}$ complexes or chelates should be stable enough to withstand luminal conditions in all gut segments prior to the site of absorption. In order to be utilized, the stability of the dietary organic $\mathrm{Zn}$ form should be low enough to allow for the release or donation of $\mathrm{Zn}$ either during or after $\mathrm{Zn}$ absorption. Previous research has shown that dietary ligands may affect both absorption and utilization of $\mathrm{Zn}$. A complete understanding of the mechanisms underlying these processes, however, is necessary to determine the specific importance of ligands. When these mechanisms are elucidated, it should be possible to develop dietary $\mathrm{Zn}$ complexes or chelates with a high biological value more effectively.

\section{REFERENCES}

Aggett, P. J. (1991). The assessment of zinc status: a personal view. Proceedings of the Nutrition Society 50, 9-17. Agricultural Research Council. (1981). The Nutrient Requirements of Pigs. Farnham Royal: Commonwealth Agricultural Bureaux.

Antonson, D. L., Barak, A. J. \& Vanderhoof, J. A. (1979). Determination of the site of zinc absorption in rat small intestine. Journal of Nutrition 109, 142-147.

Bartholomew, M. E., Tupper, R. \& Wormall, A. (1959). Incorporation of ${ }^{65} \mathrm{Zn}$ in the sub-cellular fractions of the liver and spontaneously occurring mammary tumours of mice after the injection of zinc-glycine containing ${ }^{65} \mathrm{Zn}$. Biochemical Journal 73, 256-261.

Bertoni, G., Watson, M. J., Savage, G. P. \& Armstrong, D. G. (1976). [The movements of minerals in the digestive tract of dry and lactating Jersey cows. 2. Net movements of $\mathrm{Cu}, \mathrm{Fe}, \mathrm{Mn}$ and $\mathrm{Zn}$.] Zootecnica e Nutrizione Animale 2, 185-191.

Blakeborough, P. \& Salter, D. N. (1987). The intestinal transport of zinc studied using brush-border-membrane vesicles from the piglet. British Journal of Nutrition 57, 45-55.

Bremner, I. (1983). The roles of metallothionein in the metabolism of copper and zinc. Annual Report of Studies in Animal Nutrition and Allied Sciences, Rowett Research Institute 39, 13-28.

Bremner, I. \& Beattie, J. H. (1990). Metallothionein and the trace minerals. Annual Review of Nutrition 10,63-83.

Bronner, F. (1987). Intestinal calcium absorption: mechanisms and applications. Journal of Nutrition 117, 1347-1352.

Cassens, R. G., Hoekstra, W. G., Faltin, E. C. \& Briskey, E. J. (1967). Zinc content and subcellular distribution in red vs. white porcine skeletal muscle. American Journal of Physiology 212, 688-692.

Coppen, D. E. \& Davies, N. T. (1987). Studies on the effects of dietary zinc dose on ${ }^{65} \mathrm{Zn}$ absorption in vivo and on the effects of $\mathrm{Zn}$ status on ${ }^{65} \mathrm{Zn}$ absorption and body loss in young rats. British Journal of Nutrition 57, $35-44$.

Cossack, Z. T. (1986). Somatomedin-C and zinc status in rats as affected by $\mathrm{Zn}$, protein and food intake. British Journal of Nutrition 56, 163-169.

Cousins, R. J. (1985). Absorption, transport, and hepatic metabolism of copper and zinc: special reference to metallothionein and ceruloplasmin. Physiological Reviews 65, 238-309.

Cousins, R. J. (1989). Theoretical and practical aspects of zinc uptake and absorption. In Mineral Absorption in the Monogastric GI Tract, pp. 3-12 [F. R. Dintzis and J. A. Laszlo, editors]. New York, NY: Plenum Press.

Cousins, R. J. \& Lee-Ambrose, L. M. (1992). Nuclear zinc uptake and interactions and metallothionein gene expression are influenced by dietary zinc in rats. Journal of Nutrition 122, 56-64.

Crofton, R. W., Clapham, M., Humphries, W. R., Aggett, P. J. \& Mills, C. F. (1983). Leucocyte and tissue zinc concentrations in the growing pig. Proceedings of the Nutrition Society 42, 128A (Abstr.). 
Dahmer, E. J., Coleman, B. W., Grummer, R. H. \& Hoekstra, W. G. (1972). Alleviation of parakeratosis in zinc deficient swine by high levels of dietary histidine. Journal of Animal Science 35, 1181-1189.

Davies, N. T. (1980). Studies on the absorption of zinc by rat intestine. British Journal of Nutrition 43, $189-203$.

Davies, N. T. \& Reid, H. (1979). An evaluation of the phytate, zinc, copper, iron and manganese contents of, and $\mathrm{Zn}$ availability from, soya-based textured-vegetable-protein meat-substitutes or meat-extenders. British Journal of Nutrition 41, 579-589.

Dørup, 1. \& Clausen, T. (1991). Effects of magnesium and zinc deficiencies on growth and protein synthesis in skeletal muscle and the heart. British Journal of Nutrition 66, 493-504.

Dørup, I., Flyvbjerg, A., Everts, M. E. \& Clausen, T. (1991). Role of insulin-like growth factor-1 and growth hormone in growth inhibition induced by magnesium and zinc deficiencies. British Journal of Nutrition 66, 505-521.

Droke, E. A., Spears, J. W., Armstrong, J. D., Kegley, E. B. \& Simpson, R. B. (1993). Dietary zinc affects serum concentrations of insulin and insulin-like growth factor $I$ in growing lambs. Journal of Nutrition 123, $13-19$.

El-Shobaki, F. A. \& Srour, M. G. (1989). The influence of ascorbic acid and lactose on the interaction of iron with each of cobalt and zinc during intestinal absorption. Zeitschrift fur Ernährungswissenschaft 28, 310-315.

Evans, G. W. \& Johnson, E. C. $(1980 a)$. Zinc absorption in rats fed a low-protein diet and a low-protein diet supplemented with tryptophan or picolinic acid. Journal of Nutrition 110, 1076-1080.

Evans, G. W. \& Johnson, E. C. $(1980 b)$. Zinc concentration of liver and kidneys from rat pups nursing dams fed supplemental zinc dipicolinate or zinc acetate. Journal of Nutrition 110, 2121-2124.

Evans, G. W. \& Johnson, E. C. $(1980 \mathrm{c})$. Growth stimulating effect of picolinic acid added to rat diets. Proceedings of the Society for Experimental Biology and Medicine 165, 457-461.

Evans, G. W. \& Johnson, P. E. (1979). Purification and characterization of a zinc-binding ligand in human milk. Federation Proceedings 38, 703.

Fairweather-Tait, S. J., Jackson, M. J., Fox, T. E., Wharf, S. G., Eagles, J. \& Croghan, P. C. (1993). The measurement of exchangeable pools of zinc using the stable isotope ${ }^{70} \mathrm{Zn}$. British Journal of Nutrition 70 , 221-234.

Fischer, P. W. F. \& L'Abbe, M. R. (1985). Copper transport by intestinal brush border membrane vesicles from rats fed high zinc or copper deficient diets. Nutrition Research 5, 759-767.

Flanagan, P. R., Haist, J. \& Valberg, L. S. (1983). Zinc absorption, intraluminal zinc and intestinal metallothionein levels in zinc-deficient and zinc-repleted rodents. Journal of Nutrition 113, 962-972.

Galdes, A. \& Vallee, B. L. (1983). Categories of zinc metalloenzymes. In Zinc and its Role in Biology and Nutrition (Metal lons in Biological Systems vol. 15), pp. 1-54 [H. Sigel and A. Sigel, editors]. New York: Marcel Dekker, Inc.

Giroux, E. \& Prakash, N. J. (1977). Influence of zinc-ligand mixtures on serum zinc levels in rats. Journal of Pharmaceutical Sciences 66, 391-395.

Giugliano, R. \& Millward, D. J. (1984). Growth and zinc homeostasis in the severely Zn-deficient rat. British Journal of Nutrition 52, 545-560.

Giugliano, R. \& Millward, D. J. (1987). The effects of severe zinc deficiency on protein turnover in muscle and thymus. British Journal of Nutrition 57, 139-155.

Golden, B. E. (1989). Zinc in cell division and tissue growth: physiological aspects. In Zinc in Human Biology, pp. 119-128 [C. F. Mills, editor]. London: Springer-Verlag.

Grace, N. D. (1975). Studies on the flow of zinc, cobalt, copper and manganese along the digestive tract of sheep given fresh perennial ryegrass, or white or red clover. British Journal of Nutrition 34, 73-82.

Grace, N. D. (1983). Amounts and distribution of mineral elements associated with fleece-free empty body weight gains in the grazing sheep. New Zealand Journal of Agricultural Research 26, 59-70.

Greene, L. W., Lunt, D. K., Byers, F. M., Chirase, N. K., Richmond, C. E., Knutson, R. E. \& Schelling, G. T. (1988). Performance and carcass quality of steers supplemented with zinc oxide or zinc methionine. Journal of Animal Science 66, 1818-1823.

Gupta, R. P., Verma, P. C. \& Gupta, R. K. P. (1985). Experimental zinc deficiency in guinea-pigs: clinical signs and some haematological studies. British Journal of Nutrition 54, 421-428.

Hallmans, G., Nilsson, U., Sjöstrom, R., Wetter, L. \& Wing, K. (1987). The importance of the body's need for zinc in determining $\mathrm{Zn}$ availability in food: a principle demonstrated in the rat. British Journal of Nutrition $\mathbf{5 8}$, $59-64$.

Hambidge, K. M., Casey, C. E. \& Krebs, N. F. (1986). Zinc. In Trace Elements in Human and Animal Nutrition, 5th Edn, vol. 2, pp. 1-137 [W. Mertz, editor]. London: Academic Press.

Hamilton, D. L., Bellamy, J. E. C., Valberg, J. D. \& Valberg, L. S. (1978). Zinc, cadmium, and iron interactions during intestinal absorption in iron-deficient mice. Canadian Journal of Physiology and Pharmacology 56, 384-389.

Harmuth-Hoene, A. E. \& Meuser, F. (1987). [Biological availability of zinc in whole-grain cereal products with various phytate contents.] Zeitschrift für Ernährungswissenschaft 26, 250-267.

Hempe, J. M. \& Cousins, R. J. (1989). Effect of EDTA and zinc-methionine complex on zinc absorption by rat intestine. Journal of Nutrition 119, 1179-1187.

Hempe, J. M. \& Cousins, R. J. (1992). Cysteine-rich intestinal protein and intestinal metallothionein: an inverse relationship as a conceptual model for zinc absorption in rats. Journal of Nutrition 122, 89-95. 
Hill, D. A., Peo, E. R. \& Lewis, A. J. (1987). Influence of picolinic acid on the uptake of ${ }^{65} \mathrm{Zn}$-amino acid complexes by the everted rat gut. Journal of Animal Science 65, 173-178.

Hill, D. A., Peo, E. R., Lewis, A. J. \& Crenshaw, J. D. (1986). Zinc-amino acid complexes for swine. Journal of Animal Science 63, 121-130.

Hoekstra, W. G., Faltin, E. C., Lin, C. W., Roberts, H. F. \& Grummer, R. H. (1967). Zinc deficiency in reproducing gilts fed a diet high in calcium and its effect on tissue zinc and blood serum alkaline phosphatase. Journal of Animal Science 26, 1348-1357.

Hoekstra, W. G., Lewis, P. K., Phillips, P. H. \& Grummer, R. H. (1956). The relationship of parakeratosis, supplemental calcium and zinc to the zinc content of certain body components of swine. Journal of Animal Science 15, 752-764.

Hunt, J. R. \& Johnson, L. K. (1992). Dietary protein, as egg albumen: effects on bone composition, zinc bioavailability and zinc requirements of rats, assessed by a modified broken-line model. Journal of Nutrition 122 , 161-169.

Hunt, J. R. \& Larson, B. J. (1990). Meal protein and zinc levels interact to influence zinc retention by the rat. Nutrition Research 10, 697-705.

Jackson, M. J. (1989). Physiology of zinc: general aspects. In Zinc in Human Biology, pp. 1-14 [C. F. Mills, editor]. London: Springer-Verlag.

Johanning, G. L., Browning, J. D., Bobilya, D. J., Veum, T. L. \& O’Dell, B. L. (1990). Effect of zinc deficiency and food restriction in the pig on erythrocyte fragility and plasma membrane composition. Nutrition Research 10, 1463-1471.

Kernkamp, H. C. H. \& Ferrin, E. F. (1953). Parakeratosis in swine. Journal of American Veterinary Medical Association 123, 217-220.

King, J. C. (1990). Assessment of zinc status. Journal of Nutrition 120, 1474-1479.

Kornegay, E. T. \& Thomas, H. R. (1975). Zinc-proteinate supplement studied. Hog Farm Management (August), $50-51$.

Kratzer, F. H. \& Vohra, P. (1986). Chelates in Nutrition. Boca Raton, FL: CRC Press, Inc.

Menard, M. P. \& Cousins, R. J. (1983). Zinc transport by brush border membrane vesicles from rat intestine. Journal of Nutrition 113, 1434-1442.

Menard, M. P., McCormick, C. C. \& Cousins, R. J. (1981). Regulation of intestinal metallothionein biosynthesis in rats by dietary zinc. Journal of Nutrition 111, 1353-1361.

Miller, E. R., Luecke, R. W., Ullrey, D. E., Baltzer, B. V., Bradley, B. L. \& Hoefer, J. A. (1968). Biochemical, skeletal and allometric changes due to zinc deficiency in the baby pig. Journal of Nutrition 95, 278-286.

Miller, J. K. \& Cragle, R. G. (1965). Gastrointestinal sites of absorption and endogenous secretion of zinc in dairy cattle. Journal of Dairy Science 48, 370-373.

Miller, J. K. \& Jensen, L. S. (1966). Effect of dietary protein source on zinc absorption and excretion along the alimentary tracts of chicks. Poultry Science 45, 1051-1053.

Miller, W. J., Neathery, M. W., Gentry, R. P., Blackmon, D. M. \& Stake, P. E. (1974). Adaptations in zinc metabolism by lactating cows fed a low-zinc practical-type diet. In Trace Element Metabolism in Animals-2, pp. 550-552 [W. G. Hoekstra, J. W. Suttie, H. E. Ganther and W. Mertz, editors]. Baltimore, MD: University Park Press.

Morgan, D. P., Young, E. P., Earle, I. P., Davey, R. J. \& Stevenson, J. W. (1969). Effects of dietary calcium and zinc on calcium, phosphorus and zinc retention in swine. Journal of Animal Science 29, 900-905.

National Research Council, Subcommittee on Zinc. (1979). Zinc. Baltimore, MD: University Park Press.

National Research Council. (1988). Nutrient Requirements of Swine, 10th ed. Washington, DC: National Academy Press.

O'Dell, B. L. (1984). Bioavailability of trace elements. Nutrition Reviews 42, 301-308.

O'Dell, B. L., Burpo, C. E. \& Savage, J. E. (1972). Evaluation of zinc availability in foodstuffs of plant and animal origin. Journal of Nutrition 102, 653-660.

Oestreicher, P. \& Cousins, R. J. (1989). Zinc uptake by basolateral membrane vesicles from rat small intestine. Journal of Nutrition 119, 639-646.

Owen, A. A., Peo, E. R., Cunningham, P. J. \& Moser, B. D. (1973). Effect of EDTA on utilization of dietary zinc by G-F swine. Journal of Animal Science 37, 470-478.

Pallauf, J., Höhler, D. \& Rimbach, G. (1992). [Effect of microbial phytase supplementation to a maize-soya diet on the apparent absorption of $\mathrm{Mg}, \mathrm{Fe}, \mathrm{Cu}, \mathrm{Mn}$ and $\mathrm{Zn}$ and parameters of $\mathrm{Zn}$ status in piglets]. Journal of Animal Physiology and Nutrition 68, 1-9.

Partridge, I. G. (1978). Studies on digestion and absorption in the intestines of growing pigs. 4. Effects of dietary cellulose and sodium levels on mineral absorption. British Journal of Nutrition 39, 539-545.

Pimentel, J. L., Cook, M. E. \& Greger, J. L. (1991). Bioavailability of zinc-methionine for chicks. Poultry Science 70, 1637-1639.

Prasad, A.S. (1988). Zinc in growth and development and spectrum of human zinc deficiency. Journal of the American College of Nutrition 7, 377-384.

Prasad, A. S., Oberleas, D., Miller, E. R. \& Luecke, R. W. (1971). Biochemical effects of zinc deficiency: changes in activities of zinc-dependent enzymes and ribonucleic acid and deoxyribonucleic acid content of tissues. Journal of Laboratory and Clinical Medicine 77, 144-152. 
Richards, M. P. (1989). Recent developments in trace element metabolism and function: role of metallothionein in copper and zinc metabolism. Journal of Nutrition 119, 1062-1070.

Richards, M. P. \& Cousins, R. J. (1975). Mammalian zinc homeostasis: requirement for RNA and metallothionein synthesis. Biochemical and Biophysical Research Communications 64, 1215-1223.

Roth, H. P. \& Kirchgessner, M. (1985). Utilization of zinc from picolinic or citric acid complexes in relation to dietary protein source in rats. Journal of Nutrition 115, 1641-1649.

Roth-Bassell, H. A. \& Clydesdale, F. M. (1991). The influence of zinc, magnesium, and iron on calcium uptake in brush border membrane vesicles. Journal of the American College of Nutrition 10, 4449.

Schölmerich, J., Freudemann, A., Köttgen, E., Wietholz, H., Steiert, B., Löhle, B., Häussinger, D. \& Gerok, W. (1987). Bioavailability of zinc from zinc-histidine complexes. I. Comparison with zinc sulfate in healthy men. American Journal of Clinical Nutrition 45, 1480-1486.

Seal, C. J. \& Heaton, F. W. (1983). Chemical factors affecting the intestinal absorption of zinc in vitro and in vivo. British Journal of Nutrition 50, 317-324.

Seal, C. J. \& Heaton, F. W. (1985). Effect of dietary picolinic acid on the metabolism of exogenous and endogenous zinc in the rat. Journal of Nutrition 115, 986-993.

Seal, C. J. \& Mathers, J. C. (1989). Intestinal zinc transfer by everted gut sacs from rats given diets containing different amounts and types of dietary fibre. British Journal of Nutrition 62, 151-163.

Seguin, C. \& Hamer, D. H. (1987). Regulation in vitro of metallothionein gene binding factors. Science 235, 1383-1387.

Shurson, G. C., Ku, P. K., Waxler, G. L., Yokoyama, M. T. \& Miller, E. R. (1990). Physiological relationships between microbiological status and dietary copper levels in the pig. Journal of Animal Science 68, 1061 1071.

Simons, P. C. M., Versteegh, H. A. J., Jongbloed, A. W., Kemme, P. A., Slump, P., Bos, K. D., Wolters, M. G. E., Beudeker, R. F. \& Verschoor, G. J. (1990). Improvement of phosphorus availability by microbial phytase in broilers and pigs. British Journal of Nutrition 64, 525-540.

Smith, D. W. (1990). Inorganic Substances. Cambridge: University Press.

Solomons, N. W. \& Jacob, R. A. (1981). Studies on the bioavailability of zinc in humans: effects of heme and nonheme iron on the absorption of zinc. American Journal of Clinical Nutrition 34, 475-482.

Solomons, N. W., Pineda, O., Viteri, F. \& Sandstead, H. H. (1983). Studies on the bioavailability of zinc in humans: mechanism of the intestinal interaction of nonheme iron and zinc. Journal of Nutrition 113, 337-349.

Southon, S., Gee, J. M., Bayliss, C. E., Wyatt, G. M., Horn, N. \& Johnson, I. T. (1986). Intestinal microflora, morphology and enzyme activity in zinc-deficient and Zn-supplemented rats. British Journal of Nutrition 55, 603-611.

Spears, J. W. (1989). Zinc methionine for ruminants: relative bioavailability of zinc in lambs and effects of growth and performance of growing heifers. Journal of Animal Science 67, 835-843.

Spears, J. W. \& Kegley, E. B. (1991). Effect of zinc and manganese methionine on performance of beef cows and calves. Journal of Animal Science 69 Suppl. 1, 59.

Spears, J. W., Kegley, E. B. \& Ward, J. D. (1991). Bioavailability of organic, inorganic trace minerals explored. Feedstuffs (November), 12-20.

Spray, C. M. \& Widdowson, E. M. (1950). The effect of growth and development on the composition of mammals. British Journal of Nutrition 4, 332-352.

Starcher, B. C., Glauber, J. G. \& Madaras, J. G. (1980). Zinc absorption and its relationship to intestinal metallothionein. Journal of Nutrition 110, 1391-1397.

Steel, L. \& Cousins, R. J. (1985). Kinetics of zinc absorption by luminally and vascularly perfused rat intestine. American Journal of Physiology 248, G46-G53.

Stryer, L. (1988). Biochemistry, 3rd ed. New York, NY: W. H. Freeman and Co.

Sturniolo, G. C., Montino, C., Rossetto, L., Martin, A., D'Inca, R., D’Odorico, A. \& Naccarato, R. (1991). Inhibition of gastric acid secretion reduces zinc absorption in man. Journal of American College of Nutrition 10, $372-375$.

Swinkels, J. W. G. M., Kornegay, E. T., Zhou, W., Lindemann, M. D., Webb, K. E. \& Verstegen, M. W. A. $(1994 a)$. Effectiveness of a zinc amino acid chelate and zinc sulfate in repleting serum and soft tissue zinc pools when fed to zinc depleted pigs. Journal of Animal Science, submitted.

Swinkels, J. W. G. M., Kornegay, E. T., Zhou, W., Lindemann, M. D., Webb, K. E. \& Verstegen, M. W. A. $(1994 \mathrm{~b})$. In vivo assessment of rate and site of apparent zinc, copper and iron absorption as affected by $\mathrm{Zn}$ source using $\mathrm{Zn}$ depleted pigs. Journal of Animal Science, submitted..

Swinkels, J. W. G. M., Kornegay, E. T., Zhou, W., Wong, E. A., Lindemann, M. D. \& Verstegen, M. W. A. $(1994 c)$. Serum mitogenic activity, total pituitary RNA and growth hormone mRNA concentrations of experimentally zinc depleted pigs. Journal of Nutrition (In press).

Tacnet, F., Watkins, D. W. \& Ripoche, P. (1990). Studies of zinc transport into brush-border membrane vesicles isolated from pig small intestine. Biochimica et Biophysica Acta 1024, 323-330.

Todd, W. R., Elvehjem, C. A. \& Hart, E. B. (1934). Zinc in the nutrition of the rat. American Journal of Physiology 107, 146-156.

Tucker, H. F. \& Salmon, W. D. (1955). Parakeratosis or zinc deficiency disease in the pig. Proceedings of the Society for Experimental Biology and Medicine 88, 613-616.

Underwood, E. J. (1977). Trace Elements in Human and Animal Nutrition, 4th ed. London: Academic Press. 
Van Campen, D. R. \& Mitchell, E. A. (1965). Absorption of $\mathrm{Cu}^{64}, \mathrm{Zn}^{65}, \mathrm{Mo}^{99}$, and $\mathrm{Fe}^{59}$ from ligated segments of the rat gastrointestinal tract. Journal of Nutrition 86, 120-124.

Vasak, M. \& Kägi, J. H. R. (1983). Spectroscopic properties of metallothionein. In Zinc and its Role in Biology and Nutrition (Metal lons in Biological Systems vol. 15), pp. 213-273 [H. Sigel and A. Sigel, editors]. New York, NY: Marcel Dekker, Inc.

Verma, P. C., Gupta, R. P., Sadana, J. R. \& Gupta, R. K. P. (1988). Effect of experimental zinc deficiency and repletion on some immunological variables in guinea-pigs. British Journal of Nutrition 59, 149-154.

Wapnir, R. A., Garcia-Aranda, J. A., Mevorach, D. E. K. \& Lifshitz, F. (1985). Differential absorption of zinc and low-molecular-weight ligands in the rat gut in protein-energy malnutrition. Journal of Nutrition 115, 900-908.

Wapnir, R. A. \& Stiel, L. (1986). Zinc intestinal absorption in rats: specificity of amino acids as ligands. Journal of Nutrition 116, 2171-2179.

Wapnir, R. A., Stiel, L. \& Lee, S.-Y. (1989). Zinc intestinal absorption : effect of carbohydrates. Nutrition Research 9, $1277-1284$.

Wedekind, K. J. \& Baker, D. H. (1990). Zinc bioavailability in feed-grade sources of zinc. Journal of Animal Science 68, 684-689.

Wedekind, K. J., Hortin, A. E. \& Baker, D. H. (1992). Methodology for assessing zinc bioavailability: efficacy estimates for zinc-methionine, zinc sulfate and zinc oxide. Journal of Animal Science 70, 178-187.

Williams, R. J. P. (1984). Zinc: what is its role in biology? Endeavour 8, 65-70.

Williams, R. J. P. (1989). An introduction to the biochemistry of zinc. In Zinc in Human Biology, pp. 15-31 [C. F. Mills, editor]. London: Springer-Verlag.

Wu, F. Y,-H. \& Wu, C.-W. (1983). The role of zinc in DNA and RNA polymerases. In Zinc and its Role in Biology and Nutrition (Metal Ions in Biological Systems vol. 15), pp. 157-192 [H. Sigel and A. Sigel, editors]. New York, NY: Marcel Dekker, Inc.

Yasodhara, P., Ramaraju, L. A. \& Raman, L. (1991). Trace minerals in pregnancy. 1. Copper and zinc. Nutrition Research 11, 15-21.

Zhou, W., Kornegay, E. T., Lindemann, M. D., Swinkels, J. W. G. M., Welten, M. K. \& Wong, E. A. (1994). Stimulation of growth by intravenous injection of copper in weanling pigs. Journal of Animal Science (In press). 